\title{
THE EMPIRICAL RESEARCH OF HAWGENT DYNAMIC MATHEMATICS TECHNOLOGY INTEGRATED INTO TEACHING FRACTION IN PRIMARY SCHOOL
}

\author{
Tommy Tanu Wijaya, Zhou Ying, Aditya Purnama \\ School of Mathematics and Statistics, Guangxi Normal University, Guilin, China \\ tanuwijayat@gmail.com
}

\begin{abstract}
STEAM education that is under ICT has become an upsurge in the international education of research and practice. Due to this, there is a wide application of information technology that has a profound impact to mathematics education. Based on the multiple representation of mathematics, this research aims to test the effectiveness of Hawgent dynamic mathematic software in teaching mathematics to primary students. The sample of this study are all the primary students in Bandung and this research uses the test and non-test method. The test method is a quantitative test to know the students' mathematical understanding ability when using Hawgent and traditional teaching method. The data collected from the test method would be the post-test scores and the scores are both from the experimental and controlled class. The data will then be process by using SPSS 22 and Microsoft Excel. The data is then analyzed by using the t-test statistic. The result of this study concludes that the students' understanding ability whose learning are supported by Hawgent are better than whose learning are using the traditional teaching method.
\end{abstract}

Keywords: Hawgent Dynamic Mathematic Software, understanding ability

\begin{abstract}
Abstrak
Pendidikan STEAM yang berada di bawah TIK telah menjadi peningkatan dalam pendidikan internasional untuk penelitian dan praktik. Karena ini, ada banyak aplikasi teknologi informasi yang memiliki dampak mendalam pada pendidikan matematika. Berdasarkan beberapa representasi matematika, penelitian ini bertujuan untuk menguji efektivitas perangkat lunak matematika dinamis Hawgent dalam mengajar matematika untuk siswa sekolah dasar. Sampel penelitian ini adalah semua siswa sekolah dasar di Bandung dan penelitian ini menggunakan metode tes dan non-tes. Metode tes adalah tes kuantitatif untuk mengetahui kemampuan pemahaman matematis siswa ketika menggunakan metode pengajaran Hawgent dan tradisional. Data yang dikumpulkan dari metode tes adalah skor post-test dan skor keduanya dari kelas eksperimen dan terkontrol. Data kemudian akan diproses dengan menggunakan SPSS 22 dan Microsoft Excel. Data tersebut kemudian dianalisis dengan menggunakan statistik t-test. Hasil penelitian ini menyimpulkan bahwa kemampuan pemahaman siswa yang pembelajarannya didukung oleh Hawgent lebih baik daripada yang pembelajarannya menggunakan metode pengajaran tradisional.
\end{abstract}

Kata kunci: Software Matematika Hawgent Dynamic, Kemampuan Pemahaman

\section{INTRODUCTION}

Mathematics understanding is a very important part in understanding mathematical problems and various problems in our daily life (Dini et al. 2018). Various fractions such as ordinary, mixed and decimal fractions can explain and solves daily life problems. Primary schools' curriculum is considered difficult where the competency standard is understanding simple fractions and its use in problem solving. There are some difficulties that are faced by students such as hearing, speaking, reading and mathematical ability. Mathematics learning should be directed to build a thorough understanding and usage of mathematics in ouside mathematics contexts by developing the mathematical connection between various ideas, understanding how mathematical ideas are interrelated to one another (Wijaya et al. 2018).

Students have difficulties in proving and write mathematical notations or use the mathematical 
language correctly because most of them do not understand the mathematical concepts and definitions (Dewi et al. 2018). With this we can see that the students' proving ability is closely related to their mathematical understanding ability (David, 2002). Bloom divides the aspects of understanding into three different kinds which are: translation, interpretation, and exploration (Tambychik T. \& Subahan T., 2010). Translation is the ability to understand an idea and express it in another way such as changing a mathematical story into a mathematical sentence. Interpretation is the ability to understand and connect a known material or ideas then explain it in detail. While exploration is the understanding that expects people to make conclusions and provide their own point of view to the problem. By knowing the students' mathematical understanding ability, the teacher would be able to know problems that are faced by the students. With these infromation, the teacher would be able to design the right learning media so that the delivery of the topic would be optimum and an increase in the students' achievement. According to Tambychik (Hidayatullah et al, 2008), understanding difficulties faced by students on a specific mathematics skill is crucial as it can lead to a more meaningful teaching and learning process.

Hawgent Dynamic Teaching Software ( $\Omega$ edition) is a powerful and easy-to-use tool for mathematics teaching that is recently introduced by Hawgent Mathematical Technology Center in 2018 (Xie et al, 2018). Hawgent dynamic mathematic software has a powerful tool commands which allow users to customize tools and commands that includes editing existing menus and commands, and adding a new batch of menus and commands (Cunhua et al. 2019). There are some menu commands that needs to be licensed (register or logging in) before they can be use.

According to De Porter research in (Bernard and Chotimah 2018), it was proved that visual is more powerful than listening and reading where in humans can absorb more than $70 \%$ of the knowledge if they do it themselves. But if they only listen and see, they can only absorb 50\%. If they only see something, they can only absorb $20 \%$ and they can only absorb $10 \%$ by reading something. They also stated that ICT-assisted learning media can applicator the basic concept of mathematics for high school students . The students were able to make mathematics conclusion without having to memorize the formula of opportunity. With this in mind, we believe that Hawgent dynamic mathematic software would be able to help students even more when they are learning mathematics.

\section{METHOD}

This research uses the experimental design where the sample students will be divided into 2 classes which are the experimental and controlled class(Andini et al. 2018). The experimental class will be taught using Hawgent Dynamic Mathematic Software while the controlled class will be taught using the traditional teaching method. This research uses the pre-test and post-test method. Both classes were given a pre-test and post-tests with the same quality and quantity to be able to keep the reliability of the research. The test is done to know the affectivity of Hawgent Dynamic Mathematic Software towards the students' understanding ability. The sample for this research would be 30 primary students from West Bandung, Indonesia. The research design is shown below. 
A $0 \times 0$

A $0 \quad 0$

A: classroom random sampling

0 : Pre-test and post-test of mathematical understanding ability.

$\mathrm{X}$ : students that learns fraction with hawgent dynamic mathematical software.

\section{RESULTS}

The table below shows the result of the pre-test, post-test, average and standard deviation that were obtained from the experimental and controlled classes.

\section{Table 1}

Pre-test results of Controlled and Experimental Classes

\begin{tabular}{|c|c|c|c|c|c|}
\hline \multicolumn{2}{|c|}{ Statistic } & \multicolumn{2}{c|}{ Pre-test } & \multicolumn{2}{c|}{ Post-test } \\
\hline \multicolumn{2}{|c|}{} & $\begin{array}{c}\text { Controlled } \\
\text { Class }\end{array}$ & $\begin{array}{c}\text { Experimental } \\
\text { Class }\end{array}$ & $\begin{array}{c}\text { Controlled } \\
\text { Class }\end{array}$ & $\begin{array}{c}\text { Experimental } \\
\text { Class }\end{array}$ \\
\hline \multirow{3}{*}{$\begin{array}{c}\text { Understanding } \\
\text { Ability }\end{array}$} & $\mathrm{N}$ & 40 & 40 & 40 & 40 \\
\cline { 2 - 6 } & $\mathrm{X}$ & 80.70 & 78.77 & 86.42 & 95.90 \\
\cline { 2 - 6 } & St. Dev. & 0.81 & 0.89 & 2.61 & 2.83 \\
\cline { 2 - 6 } & & & & & \\
\hline
\end{tabular}

According to Table 1, the average score in experimental class for their understanding ability score was 78.77 while in the controlled class, their average understanding ability score was $80.70 \mathrm{We}$ can see that there is no significant difference between the two classes and so we can conclude that the understanding ability of the two classes towards mathematics are the same in the beginning.

In the post-test, the average score of the experimental class is 95.90 while the average score of the controlled class is 86.45 . With this we can see that the experimental class is doing better than the controlled class.

During the pre-test we can see that for the third question, there is a significant difference between the two classes $(\mathrm{p}=0.041<0.05)$. The average score for the controlled class is 17.38 while for the experimental class its 18.50. This shows that the class that uses Hawgent is doing better than the class that uses traditional teaching method.

Table 2

The pre-test results for controlled and experimental classes

\begin{tabular}{|c|c|c|c|}
\hline pretest & P Value & posttest & P Value \\
\hline Question 1 & 0.228 & Question 1 & 0.026 \\
\hline Question 2 & 0.115 & Question 2 & 0.92 \\
\hline Question 3 & 0.041 & Question 3 & 0.633 \\
\hline Question 4 & 0.069 & Question 4 & 0.263 \\
\hline Question 5 & 0.768 & Question 5 & 0.266 \\
\hline
\end{tabular}


The Empirical Research Of Hawgent Dynamic Mathematics Technology Integrated Into Teaching Fraction In Primary School, Tommy Tanu Wijaya, Zhou Ying, Aditya Purnama

According to table 2, The pre-test result of the experimental and controlled classes is ranked according to their scores and then they would be divided into four average parts. The average of each parts is then calculated and an independent t-test sample is carried out. The p-value result is shown below.

Table 3

The post-test results for controlled and experimental classes

\begin{tabular}{|c|c|c|c|c|}
\hline Students' score & $<25 \%$ & $25 \%-50 \%$ & $50 \%-75 \%$ & $75 \%-100 \%$ \\
\hline Average score for controlled class & 95.1 & 86.150 & 79.000 & 62.550 \\
\hline Average score for experimental class & 96.700 & 85.800 & 75.200 & 53.400 \\
\hline P Value & 0.36 & 0.896 & 0.002 & 0.964 \\
\hline
\end{tabular}

From the table 3 above, we can see that there is no significant difference in the students' average score between the two teaching methods. There is no a significant difference in the average score of the students whose score are below 25\%, 25-50\% and 75-100\% $(\mathrm{p}=0.36>0.05, \mathrm{P}=0.896>0.05, \mathrm{P}=$ $0.964>0.05$ ) but there was a significant difference in the average score of the students whose score are of the range $50-75 \%(\mathrm{p}=0.002<0.05)$.

\section{Table 4}

Normality pre-test result of controlled and experimental classes

\begin{tabular}{|c|c|c|c|c|c|c|c|}
\hline \multicolumn{2}{|l|}{ Class } & \multicolumn{3}{|c|}{ Kolmogorov-Smirnov } & \multicolumn{3}{|c|}{ Shapiro-Wilk } \\
\hline & & Statistic & $\mathrm{df}$ & Sig. & Statistic & $\mathrm{df}$ & Sig. \\
\hline ability & control & .204 & 40 & .000 & .859 & 40 & .000 \\
\hline & experiment & .215 & 40 & .000 & .822 & 40 & .000 \\
\hline
\end{tabular}

According to table 4, the significance value for both the experimental and controlled classes are 0.000 . The significance value is less than 0.05 which means that $\mathrm{H}_{0}$ is rejected and the normality test is done (Chotimah et al, 2018). The pre-test sample was not evenly distributed and as a result, the MannWhitney test was carried out.

\section{Table 5}

Mann-Whitney Test for the Pre-test

\begin{tabular}{|l|r|}
\hline & ability \\
\hline Mann-Whitney U & 615.000 \\
\hline Wilcoxon W & 1435.000 \\
\hline Z & -1.814 \\
\hline Asymp. Sig. (2-tailed) & .070 \\
\hline
\end{tabular}


In table 5 we can see that there is a significant figure of 0.70 and because the significant figure is more than 0.05 , it means that there was no significance difference in the initial mathematics understanding ability of the two classes.

after the two classes receive the teaching process, a final test (post-test) was carried out. The posttest result will be use as the basis for the research hypothesis.

\section{Table 6}

Normality post-test result of controlled and experimental classes

\begin{tabular}{|l|l|c|c|c|c|c|c|}
\hline \multicolumn{2}{|l|}{ Class } & \multicolumn{3}{|c|}{ Kolmogorov-Smirnov $^{\mathrm{a}}$} & \multicolumn{3}{|l|}{ Shapiro-Wilk } \\
\cline { 3 - 8 } \multicolumn{2}{|c|}{} & Statistic & $\mathrm{df}$ & Sig. & Statistic & df & Sig. \\
\hline \multirow{2}{*}{ ability } & control & .144 & 40 & .036 & .931 & 40 & .017 \\
\cline { 2 - 8 } & experiment & .149 & 40 & .025 & .936 & 40 & .025 \\
\hline
\end{tabular}

According to table 6, the significant value for the experimental class is 0.017 while the significant value for the controlled class is 0.025 . This means that the $\mathrm{H}_{0}$ is rejected because the significant value is less than 0.05 and that is why the normality test is done. The post-test sample was not evenly distributed and as a result, the Mann-Whitney test was carried out.

\section{Table 7}

Mann-Whitney Test for the Post-test

\begin{tabular}{|l|r|}
\hline & ability \\
\hline Mann-Whitney U & 753.000 \\
\hline Wilcoxon W & 1573.000 \\
\hline Z & -.453 \\
\hline Asymp. Sig. (2-tailed) & .045 \\
\hline
\end{tabular}

From table 7 we can see that the significant value obtained is 0.045 and because the value is less than 0.05 , the $\mathrm{H}_{0}$ is rejected (Yudhanegara M R, \& Lestari K E, 2015). It can be concluded that before the post-test was held, there is a difference in the students' mathematical understanding ability between the two classes.

In the beginning of the study, a pre-test was given to the students in both the experimental and controlled class and the average value shows that there was no significance difference in their initial mathematical understanding ability.

After the pre-test, the lessons were taught to the students with two different conditions. The experimental class studied using Hawgent Dynamic Mathematic Software while in the controlled class, the teacher uses the traditional teaching method. After the lessons were taught, the students were then given the post-test in order to find out the students' final mathematical understanding ability. From the result, we can see that the experimental class did better than the controlled class and the students that 
uses realistic mathematical learning approach understand better than students who uses the normal learning approach.

The experimental class did not face a lot of difficulties when solving the problems as they were able to solve almost all the problems. The only problems that were faced by the students in the experimental class is that they had a difficulty in working or fulfilling the indicators of algorithmic. While in the controlled class, students face a lot of difficulties when trying to solve the problem because they were not familiar with uncommon question, there is a lack of problem training and they do not have the ability to apply the indicator in the algorithmic concept.

The learning habits of the students are usually memorizing but this method does not train their thinking and problem-solving skills. This is the result of convectional teaching where the teacher teaches by applying mathematics concepts and operations then giving problem solving examples. This kind of teaching emphasize to memorize the mathematics concepts and procedures. The teaching technique is very important on the students' ability because the quality of the teacher affects the student's quality.

The problems that the teacher faced when teaching mathematics is that there is a lack of respond or enthusiasm from the students. This will require the teacher to bring life to the classroom atmosphere and stimulate classroom activity so that the students will be more enthusiastic in learning mathematics. But sometimes it becomes very difficult to encourage students to take part in the class activity and these problems are usually due to the number of students in one class.

\section{CONCLUSION}

Based on the research above, it can be concluded that Hawgent Dynamic Mathematic Software can improve the understanding ability of primary students. Using Hawgent can be an alternative learning strategy to create a learning atmosphere that is more effective, innovative, creative and fun when it is linked to everyday life. The students will find mathematics fun to learn and they will also be more active in learning mathematics.

\section{ACKNOWLEDGMENTS}

We would like to thank to Guangxi Normal University for the research fund which has been given to the researcher. This paper is based from Guangxi Zhuang Autonomous Region Postgraduate Education Innovation Project "Evaluation mathematic based on Mind Map" (XYCSR2020060).

\section{REFERENCES}

Andini, Dwi, Nenden Mulyani, Tommy Wijaya, and Devi Supriyati. 2018. "Meningkatkan Kemampuan Komunikasi Matematis Dan Self Confidence Siswa Menggunakan Pendekatan PBL Berbantuan Geogebra.” Jurnal Derivat: Jurnal Matematika dan Pendidikan Matematika 5(1): 82-93. 
Bernard M, \& Chotimah S. 2018 Improve student mathematical reasoning ability with open-ended approach using VBA for powerpoint. AIP Conference Proceedings, 2014(September). https://doi.org/10.1063/1.5054417.

Cunhua, Liu, Zhou Ying, Ouyang Qunzhuang, and Tommy Tanu Wijaya. 2019. "MATHEMATICS COURSE DESIGN BASED ON SIX QUESTIONS COGNITIVE THEORY USING HAWGENT DYNAMIC MATHEMATIC." 02(01): 36-44.

Chotimah S, Bernard M, \& Wulandari S M 2018. Contextual approach using VBA learning media to improve students' mathematical displacement and disposition ability. Journal of Physics: Conference Series, 948(1). https://doi.org/10.1088/1742-6596/948/1/012025

Dewi, Senja Noviani, Tommy Tanu Wijaya, Ayu Budianti, and Euis Eti Rohaeti. 2018. "Pengaruh Model Teams Games Tournament Terhadap Kemampuan Pemahaman Matematik Siswa Kelas XI SMK Di Kota Cimahi Pada Materi Fungsi Eksponen.” WACANA AKADEMIKA: Majalah Ilmiah Kependidikan 2(1): 99.

Dini, Mentari, Tommy Tanu Wijaya, and Asep Ikin Sugandi. 2018. "Pengaruh Self Confidence Terhadap Kemampuan Pemahaman Matematik Siswa Smp.” Jurnal Silogisme 3(1): 1-7.

David R K (2002) A Revision of Bloom's Taxonomy: An Overview Theory Into Practice,College of Education, The Ohio State University Volume 41, Number 4, 212-218.

Hidayatullah P, Akbar A M, Rahim Z (2008) Making Education Animation Using Flash.(Bandung: Informatika Bandung)

Tambychik T, Subahan T 2010 Student's Difficulties in Mathematics Problem-Solving:What do they say? International Conference on Mathematics Education Research 2010 Procedia Social and Behavioral Sciences 8 (2010) 142-151.

Wijaya, Tommy Tanu, Neng Suci Septiani Dewi, Indah Retta Fauziah, and M Afrilianto. 2018. “Analisis Kemampuan Pemahaman Matematis Siswa Kelas IX Pada Materi Bangun Ruang.” UNION: Jurnal Ilmiah Pendidikan Matematika 6(1): 19-28.

Yudhanegara M R, \& Lestari K E 2015. Meningkatkan Kemampuan Representasi Beragam Matematis Siswa melalui Pembeajaran Berbasis Masalah Terbuka (Penelitian Kuasi Eksperimen terhadap Siswa Kelas VII SMPN 1 Pagaden, Subang). Jurnal Ilmiah Solusi, 1(4), 97-106. https://doi.org/10.1017/CBO9781107415324.004

Xie D F, Chen N N, Tang J L 2018. State Mathematical Technology: Improving Mathematical Cognition. Journal of Elementary and Secondary School Teaching research (18): 7-15. 